\title{
Correlation between magma chamber deflation and eruption cloud height during the 2011 Shinmoe-dake eruptions
}

\author{
Tomofumi Kozono $^{1 *}$, Hideki Ueda ${ }^{2}$, Toshiki Shimbori ${ }^{3}$ and Keiichi Fukui ${ }^{3}$
}

\begin{abstract}
Multiple observations of subsurface and surface phenomena during volcanic eruptions provide important information about eruption styles, eruption column dynamics, and magma plumbing systems. During the 2011 eruptions of Kirishima-Shinmoe-dake volcano in Japan, borehole-type tiltmeter data and weather radar data captured the subsurface and surface phenomena, respectively; the tiltmeters detected deflation of a magma chamber caused by migration of magma to the surface, and the weather radar detected changes in the height of the eruption cloud echo. In this study, we present a method based on the correlation between magma chamber deflation and cloud echo height to identify eruption styles. The method can detect whether a column-forming eruption is accompanied by magma migration from the magma chamber (e.g., sub-Plinian eruption), or not (e.g., Vulcanian explosion). By using well-correlated chamber deflation and echo height data, we found that eruption column dynamics during the Shinmoe-dake eruptions are well described by a one-quarter power scaling relationship between cloud height and magma discharge rate, and that a clear correlation between geodetic volume change of the magma chamber and the erupted volume indicates a stable magma plumbing system connecting the magma chamber and the surface.
\end{abstract}

Keywords: Eruption style; Eruption dynamics; Magma chamber deflation; Eruption cloud height; Tiltmeter; Weather radar; Shinmoe-dake

\section{Findings Introduction}

The dynamics of volcanic eruptions are captured by multiple observations, which can include geophysical, geological, geochemical, and remote-sensing measurements. These observations allow for eruption style classification and occasionally, the detection of the precursors of eruptions (Sparks 2003). In particular, simultaneous observations of subsurface and surface phenomena may provide strong constraints on magma plumbing systems and eruption column dynamics, furthering insight of the mechanisms of diverse eruption styles.

During the 2011 andesitic eruptions of KirishimaShinmoe-dake volcano in Japan, diverse eruption styles including sub-Plinian eruptions, Vulcanian explosions,

\footnotetext{
* Correspondence: kozono@zisin.gp.tohoku.ac.jp

${ }^{1}$ Department of Geophysics, Graduate School of Science, Tohoku University, 6-3, Aramaki Aza-Aoba, Aoba-ku, Sendai, Miyagi 980-8578, Japan Full list of author information is available at the end of the article
}

and lava extrusion have been observed through various measurements (e.g., Nakada et al. 2013). Among the measurement devices, the borehole-type tiltmeters (Ueda et al. 2013) and the weather radar (Shimbori et al. 2013) have been used to simultaneously observe the subsurface and surface phenomena, respectively; the tiltmeters detected deflation of a magma chamber caused by migration of magma to the surface during eruptive events, and the weather radar detected changes in the height of eruption cloud echo during column-forming eruptions. These kinds of measurements have been reported by Hreinsdóttir et al. (2014), in which they showed the simultaneous measurements of crustal deformation and cloud height during the 2011 basaltic eruption of Grímsvötn Volcano in Iceland and indicated the usefulness of the measurements for constraining eruption dynamics.

In this study, based on the tiltmeter and the weather radar data, we investigate the variation of eruption styles, eruption column dynamics, and magma plumbing systems 
during the 2011 Shinmoe-dake eruptions. First, we present a method to identify various eruption styles during the Shinmoe-dake eruptions using the correlation pattern between the deflation rate of the magma chamber and the eruption cloud height, which are estimated from the tiltmeter and the weather radar data, respectively. This method enables us to distinguish whether the formation of eruption columns is accompanied by magma migration from the magma chamber, or not. Then, by using wellcorrelated chamber deflation and echo height data during continuously column-forming eruptions, we obtain the quantitative relationship between the eruption cloud height and the magma discharge rate and between the geodetic volume change of magma chamber and the erupted volume at the surface. These relationships are used to provide constraints on eruption column dynamics and the magma plumbing system during the Shinmoe-dake eruptions.

The 2011 Shinmoe-dake eruptions: observations and data In this study, we used the tiltmeter and the weather radar data obtained during the 2011 Shinmoe-dake eruptions. Shinmoe-dake volcano is an active andesitic stratovolcano located in southern Kyushu, Japan, and forms part of the Kirishima volcano group (Figure 1). The main phase of the 2011 eruptions began on January 26 and was characterized by sub-Plinian eruptions and subsequent lava extrusion (e.g., Kato and Yamasato 2013; Miyabuchi et al. 2013). On January 26 PM, 27 AM, and $27 \mathrm{PM}$, three major sub-Plinian eruptions were detected from weather radar eruption cloud echo measurements (Shimbori et al. 2013). From January 29 to 31, a continuous growth of a pancake-shaped mass of lava inside the summit crater was detected by synthetic aperture radar (SAR) satellite imaging analysis (Ozawa and Kozono 2013). In addition to these main events, the Japan Meteorological Agency (JMA) reported several infrasoundgenerating Vulcanian explosions (at 15:41 on January 27; 12:47 on January $28 ; 13: 57$ on January $30 ; 7: 54$ and 23:19 on February $1 ; 5: 25,10: 47$, and $15: 53$ on February 2; and 8:09 on February 3).

Borehole-type tiltmeters of the volcano observation network (V-net; 200-m deep) and high-sensitivity seismograph network (Hi-net; 100-m deep) stations operated by the National Research Institute for Earth Science and Disaster Prevention (NIED) successfully measured crustal deformation during the 2011 Shinmoe-dake eruptions, implying deflation of a source beneath the center of the Kirishima volcano group (Ueda et al. 2013). The tiltmeters are force-balanced pendulum types with a measuring range of $\pm 2 \times 10^{-3}$ radian and a resolution of $1 \times 10^{-9}$ radian (Sato et al. 1980). Ueda et al. (2013) modeled the source of deflation during the main phase of the 2011 events from January 26 to 31 by inverting tilt and GPS data for a spherical or dike source or for

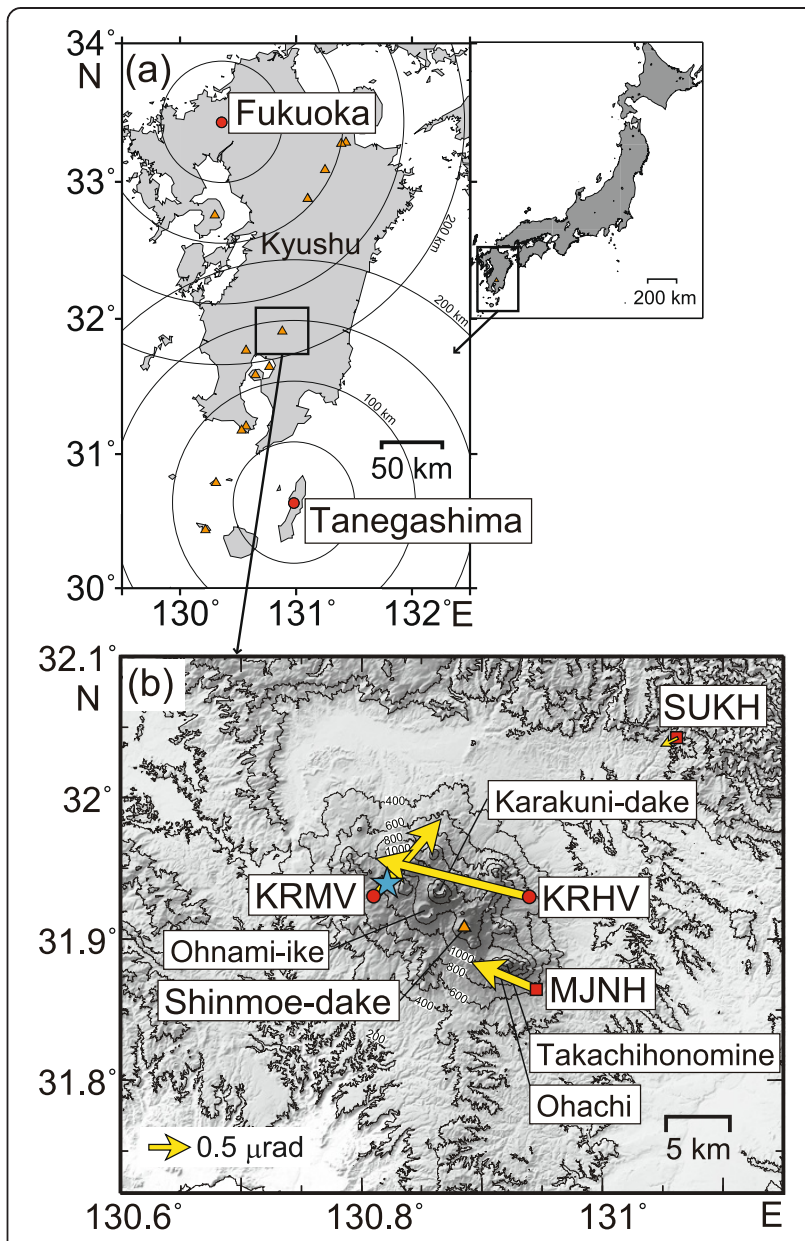

Figure 1 Locations of weather radars and tiltmeters around Shinmoe-dake volcano. (a) Location map of JMA's operational weather Doppler radars at Tanegashima and Fukuoka (red circles) with 50-km interval concentric circles. Triangles show active volcanoes. (b) Topographic map of the Kirishima volcano group in Kyushu Island, Japan, with the location of Shinmoe-dake volcano (shown by a triangle), and the locations of the tilt stations of $\mathrm{V}$-net (circles; KRHV and KRMV) and Hi-net (squares; SUKH and MJNH) networks by NIED. Observed crustal deformation in the period from January 20 to February 1, 2011 is shown as tilt-down vectors, and an asterisk indicates a surface projection of a spherical deformation source at a depth of $9.8 \mathrm{~km}$ bsl determined from tiltmeter and GPS data crustal deformation measurements (Ueda et al. 2013). Maps were constructed using 10-m mesh digital maps provided by GSI.

multiple sources (either two spherical sources, two dike sources, or a spherical and dike sources) (Mogi 1958; Okada 1992). A generic algorithm (Ueda et al. 2005) and Akaike's Information Criterion (AIC; Akaike 1974) were used to find the best-fitting parameters for each model and to select the most suitable source model. The model that best fits the tilt and GPS data with the minimum AIC value was one with a single spherical source (magma chamber), $6.5 \mathrm{~km}$ to the northwest of the summit of Shinmoe-dake, at a depth of $9.8 \mathrm{~km}$ below sea level (bsl) (Figure 1b). 
Using the tiltmeter data, Ueda et al. (2013) estimated the magnitude and the rate of volume loss of the magma chamber (referred to as 'geodetic' deflation volume and rate of the magma chamber) during the eruptions. Obviously, the magnitude and the rate depend on the assumed deformation source model. In the Shinmoe-dake eruptions, the suitable procedure for source determination described above and the fact that tilt change trends recorded by each station and the ratio of absolute tilt value changes between stations were approximately constant throughout the eruptive events (Ueda et al. 2013), strongly support the model of a single spherical source with no changes in position and shape. Therefore, the geodetic deflation volume and the rate were precisely estimated by assuming a single spherical source. Although the original tiltmeter data were sampled at $20 \mathrm{~Hz}$, we used the 10-min averaged data of the geodetic deflation volume and rate in order to adjust the sampling interval of weather radar data described below.

Operational C-band (wavelength $\approx 5.6 \mathrm{~cm}$ ) weather Doppler radars of JMA detected eruption clouds formed during the 2011 events (Shimbori et al. 2013). Shimbori et al. (2013) analyzed the data obtained from the radars at Tanegashima and Fukuoka, which are 141 and $176 \mathrm{~km}$ away from Shinmoe-dake, respectively (Figure 1a). The radars rotate at $4 \mathrm{rpm}$, and the elevation angle of the radar beam is changed as $25^{\circ}, 18^{\circ}, 13^{\circ}, 9^{\circ}, 6.3^{\circ}, 4.5^{\circ}, 4^{\circ}, 2.8^{\circ}, 2.5^{\circ}$, $1.7^{\circ}, 1.4^{\circ}, 1.2^{\circ}, 0.7^{\circ}, 0.3^{\circ}, 0.2^{\circ}, 0^{\circ}$, and $-0.3^{\circ}$ at Tanegashima; and $25^{\circ}, 19^{\circ}, 14^{\circ}, 9.8^{\circ}, 6.5^{\circ}, 4.5^{\circ}, 3.2^{\circ}, 2.8^{\circ}, 1.9^{\circ}, 1.2^{\circ}, 0.9^{\circ}$, $0.4^{\circ}, 0^{\circ},-0.3^{\circ}$, and $-0.7^{\circ}$ at Fukuoka. As a result, volume scanning or constant altitude plan position indicator (CAPPI) data are obtained in $10 \mathrm{~min}$. One difficulty with the analysis using distant radars is that the beam width in the vertical direction $\left(1.03^{\circ}\right.$ at Tanegashima and $1.01^{\circ}$ at Fukuoka) increases with distance (e.g., Oddsson et al. 2012) and spreads to approximately 2,600 to $3,100 \mathrm{~m}$ at Shinmoe-dake. In order to overcome this difficulty, the CAPPI data from these radars were synthesized, which enabled us to obtain distributions of the radar reflectivity factor with a spatial resolution of $1,000 \mathrm{~m}$.

On the basis of the vertical distributions of the radar reflectivity factor $(Z)$, Shimbori et al. (2013) estimated the height $(H)$ of the eruption cloud 'echo' as

$$
H=\frac{Z_{t}-Z_{u}}{Z_{d}-Z_{u}} H_{d}+\frac{Z_{d}-Z_{t}}{Z_{d}-Z_{u}} H_{u}
$$

where $Z_{t}$ is the discrimination threshold value of $Z$ for the eruption cloud (set as $12 \mathrm{dBZ}$ in this study), $H_{d}$ is the maximum height satisfying the condition of $Z \geq Z_{t}$, $H_{u}$ is the height at the next level of $H_{d}$, and $Z_{d}$ and $Z_{u}$ are the values of $Z$ at the heights of $H_{d}$ and $H_{u}$, respectively. As a result, changes in eruption cloud echo height were measured with a 10-min interval and a spatial resolution of $100 \mathrm{~m}$ (Shimbori et al. 2013). In response to the eruptive activities from January 26 to February 2, eruption clouds with various heights and durations have been observed.

\section{Results}

\section{Identifying eruption styles}

During the 2011 Shinmoe-dake eruptions, the correlation between the geodetic deflation rate of the magma chamber and the eruption cloud echo height dramatically changed in response to the variation in eruption styles. Figure 2 shows the time series variations of the geodetic deflation rate and the echo height in the period from January 26 to February 2. These values were estimated with a 10-min interval using the tiltmeter and the weather radar data, as shown in the previous section. Here, we present a method to identify eruption styles using the correlation between the two time series variations in Figure 2.

Figure $2 \mathrm{a}$ indicates that the correlation pattern varies in response to a change in eruption styles. During the three major sub-Plinian events on January 26 and 27 (referred to as 'P1', 'P2', and 'P3'), the correlation pattern was characterized by increases in both deflation rate and echo height. This pattern was also observed during the period between the first (P1) and second (P2) subPlinian events on January 26 and 27 and approximately at 0:00 and 7:00 on January 29, although the deflation rate and the echo height were lower than those of the sub-Plinian events. The 1.5 to $3.5-\mathrm{km}$ high (above the vent) eruption cloud echo in these events implies small-scale column-forming eruptions (referred to as 'SC'). During the lava extrusion event from January 29 to 31 , the deflation rate was moderate, whereas there was no continuous cloud echo. The high or moderate deflation rate in the above eruptive events indicates that each event was accompanied by a magma migration from the magma chamber to the surface. During most of the Vulcanian explosion (referred to as ' $V$ ' in Figure 2a), in contrast, there was no obvious change in the deflation rate, although the echo height increased for a short period. This reflects the fact that the Vulcanian explosion is accompanied only by the rupture of a high-pressurized area at a shallower part of the conduit and subsequent propagation of a fragmentation wave toward a deeper part (e.g., Turcotte et al. 1990; Koyaguchi and Mitani 2005), and not with magma migration from the magma chamber.

The above systematic relationship between the eruption style and the correlation pattern enables us to develop a method for precisely identifying eruption styles with high time resolution. This method can detect whether a columnforming eruption is accompanied by magma migration from the magma chamber (e.g., sub-Plinian eruption), or 


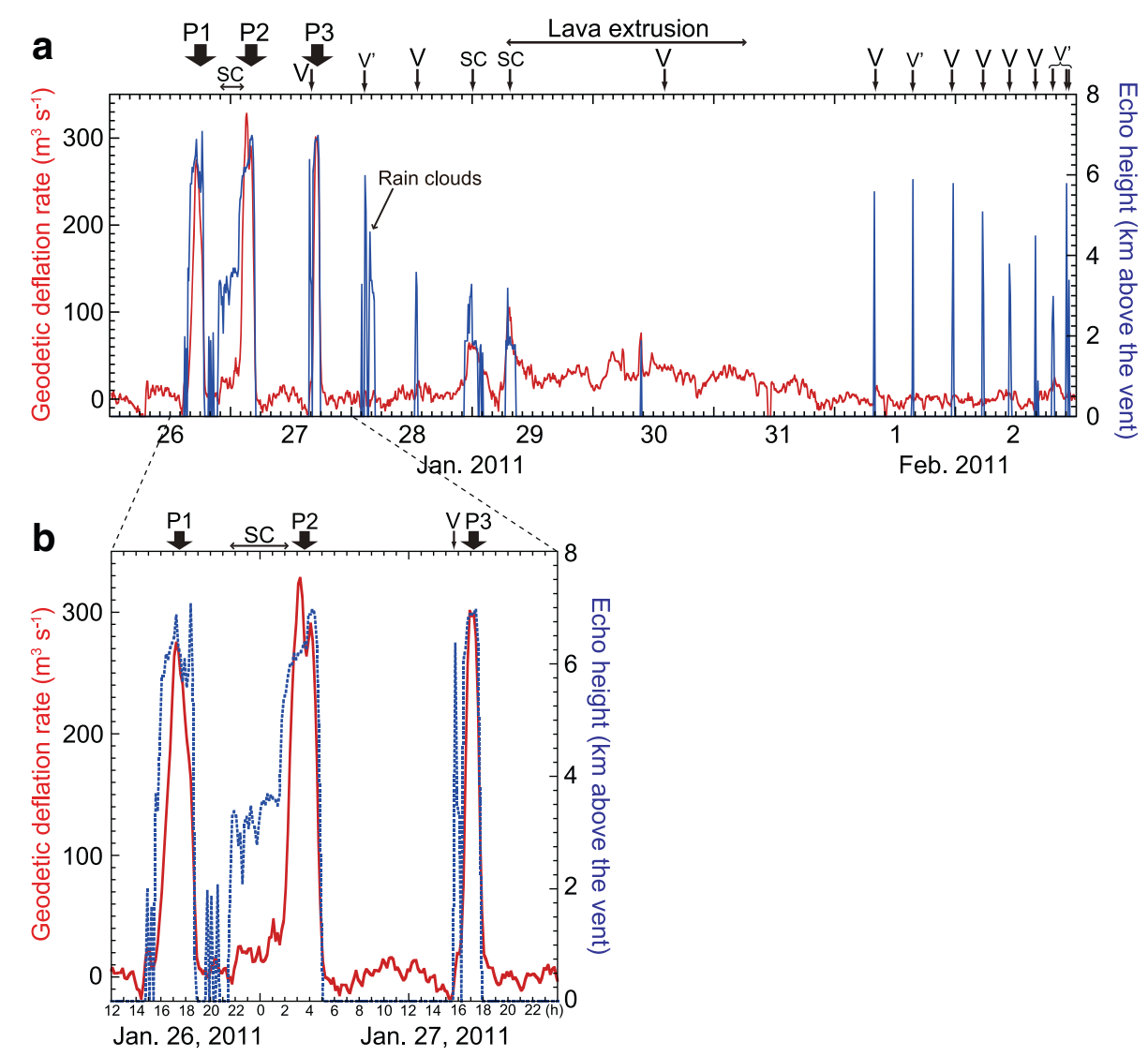

Figure 2 Time series variations of geodetic deflation rate of the magma chamber and eruption cloud height. (a) Correlation between geodetic deflation rate of the magma chamber estimated from tiltmeter data (red; Ueda et al. 2013) and eruption cloud echo height estimated from weather radar data (blue; Shimbori et al. 2013) in the 2011 Shinmoe-dake eruptions during the period from January 26 to February 2. Eruptive activities of sub-Plinian eruptions (P1, P2, and P3), Vulcanian explosions (V and V'), small-scale column-forming eruptions (SC), and lava extrusion are shown on the upper side of the figure. The echo in the morning of January 28 is deduced as rain clouds (Shimbori et al. 2013). (b) Enlarged view during the period from 12:00 on January 26 to 24:00 on January 27.

not (e.g., Vulcanian explosion). For example, our method successfully distinguished between the Vulcanian event at 15:41 on January 27 and the sub-Plinian event which occurred shortly thereafter (P3); no change occurred in the deflation rate and instantaneous increase in the echo height during the Vulcanian event, whereas an increase in both the deflation rate and the echo height occurred during the subsequent sub-Plinian event (Figure 2b).

On the basis of our method, we can also obtain new information about identification of eruption styles. Our method identified the SC events on January 29 (Figure 2a), which have not been listed in the eruption report by JMA due to no or low infrasound activity (Fukuoka Dist. Meteorol. Obs. and Kagoshima Local Meteorol. Obs. 2013). JMA reported eruptive events other than the subPlinian and lava extrusion events as Vulcanian explosions when the amplitude of infrasound exceeded a threshold. Because the SC event is considered to be accompanied by magma migration from the magma chamber to the surface, it may lead to continuous tephra emission. Indeed,
Miyabuchi et al. (2013) have revealed continuous small ash emissions during January 28-29 on the basis of tephra stratigraphy. In addition, our method identified five events characterized by a Vulcanian-type correlation pattern (labeled as $\mathrm{V}^{\prime}$ in Figure 2a), which have not been listed in the JMA report. Takeo et al. (2013) have recognized these events as Vulcanian explosions on the basis of tilt motion observations around the summit using broadband seismometers. Our method, however, cannot distinguish between an eruptive event with Vulcanian-type correlation and a purely meteorological event with rain clouds (e.g., in the morning on January 28 in Figure 2a); in both events the echo height increases, whereas no change occurs in the geodetic deflation. In such a case, seismic data is useful for distinguishing the events since the absence of volcanic seismicity rules out eruptive events.

\section{Constraints on eruption column dynamics}

When there is a clear correlation between the geodetic deflation rate of the magma chamber and the eruption 
cloud height as in the case of sub-Plinian and SC events (Figure 2), we can obtain information about eruption column dynamics by investigating the quantitative relationship between cloud height and the magma discharge rate, which is calculated from the geodetic deflation rate. Previous studies for eruption column dynamics have shown that the cloud height-discharge rate relationship is expressed by a power-law scaling: the cloud height should theoretically increase with the fourth root of discharge rate (i.e., 0.25 power), which is expected from dimensional analysis (Morton et al. 1956). Empirical compilations also roughly follow this relationship (0.259 power in Sparks et al. 1997; 0.241 power in Mastin et al. 2009). Figure 3 shows the double logarithmic plot of the echo height against the geodetic deflation rate for the sub-Plinian and SC events on January 26 and 27 (the events in Figure 2b), in which each point is obtained from the 10-min interval data in Figure 2. Here, under the assumption of no change in the magma chamber conditions throughout the eruption sequence, the magma discharge rate is proportional to the geodetic deflation rate. It should be noted that its proportionality constant generally becomes greater than one because of the compressibility of magma in the chamber (e.g., Segall 2010),

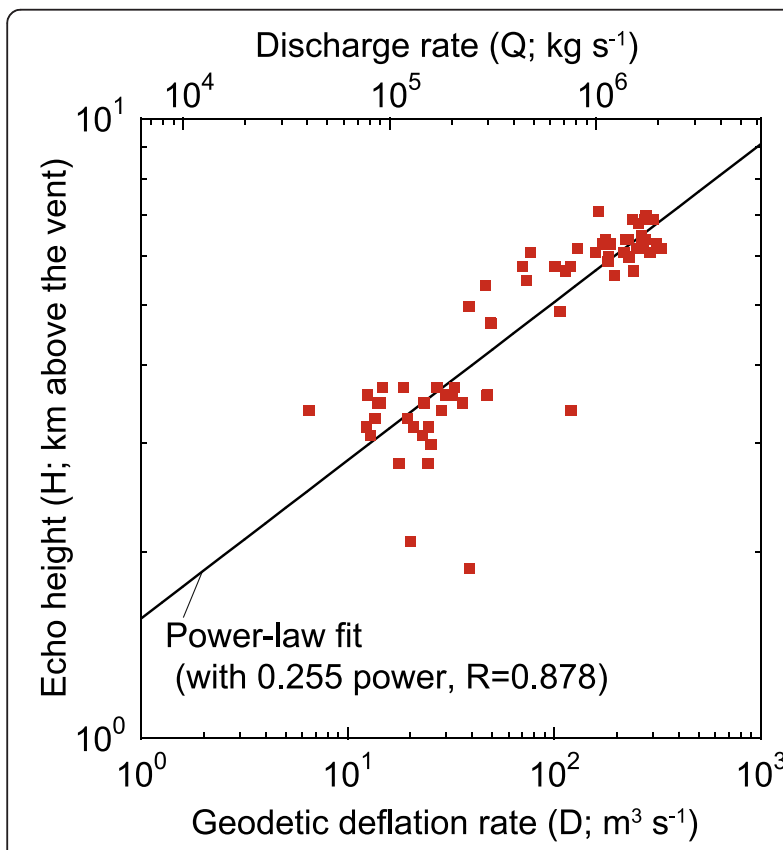

Figure 3 Magma chamber deflation rate (or discharge rate) versus cloud height on January 26 and 27 . Double logarithmic plot of eruption echo height against geodetic deflation rate of the magma chamber for the sub-Plinian and SC events on January 26 and 27 (the events in Figure 2b). A fitting line with power-law scaling is also shown ( 0.255 power, $R=0.878)$. The scale at the top of the figure represents discharge rate $Q\left(\mathrm{~kg} \mathrm{~s}^{-1}\right)$ calculated from the geodetic deflation rate $D\left(\mathrm{~m}^{3} \mathrm{~s}^{-1}\right)$ using the relationship $Q=2.5 D \rho$, where $\rho$ is density of dense rock (set to be $2,500 \mathrm{~kg} \mathrm{~m}^{-3}$ ). and it is equal to one (i.e., the discharge rate is equal to the geodetic deflation rate) only in the case that the magma is incompressible. In the 2011 Shinmoe-dake eruptions, the magnitude of the constant has been estimated as 2.28 to 2.85 from simultaneous measurements of erupted lava volume and geodetic volume change based on geodetic and satellite observations (Kozono et al. 2013). Using this constant, we calculated the discharge rate from the geodetic deflation rate and obtained the cloud height-discharge rate relationship.

The relationship between the cloud height and the geodetic deflation rate (or the discharge rate) during the sub-Plinian and SC events on January 26 and 27 is well described by power-law fitting with the power of 0.255 (Figure 3), which agrees with the theoretical relationship and the previous empirical compilations. The relationship between the cloud height in $\mathrm{km}(H)$ and the discharge rate in $\mathrm{kg} \mathrm{s}^{-1}(Q)$ is obtained as

$$
H=C Q^{0.255}
$$

where the pre-factor $C$ is in the range of 0.163 to 0.173 , which depends on the assumed range of the proportionality constant between the discharge rate and the geodetic deflation rate (2.28 to 2.85$)$. Here, the magnitude of $C$ is smaller than that obtained from the empirical compilations (0.220 in Sparks et al. 1997; 0.304 in Mastin et al. 2009). A possible reason for this small value is the effect of wind on plume height. The plume height decreases with increasing wind speed because of enhanced entrainment of air into the plume (Bursik 2001; Degruyter and Bonadonna 2012; Woodhouse et al. 2013; Suzuki and Koyaguchi 2013). In fact, atmospheric conditions around Shinmoe-dake Volcano on January 26 and 27 were characterized by a strong wind in the troposphere with a maximum speed of about $80 \mathrm{~m} \mathrm{~s}^{-1}$ at 11-km altitude (Hashimoto et al. 2012). Additionally, a 3D numerical simulation of the Shinmoe-dake eruption cloud revealed that a strong wind significantly decreases the cloud height as compared to the case with no wind (Suzuki and Koyaguchi 2013). Woodhouse et al. (2013) have shown the relationship between the pre-factor $C$ and the wind speed at the tropopause at an $11-\mathrm{km}$ altitude. According to this relationship, $C$ is calculated at approximately 0.14 when the wind speed is $80 \mathrm{~m} \mathrm{~s}^{-1}$, which roughly agrees with our result.

\section{Constraints on the magma plumbing system}

The temporal relationship between the deflation process of the magma chamber and the magma discharge process at the surface is useful for understanding the evolution of magma plumbing systems during eruptions. We can obtain this relationship on the basis of the tiltmeter and the weather radar data: the geodetic volume change of the 
magma chamber is directly estimated from the tilt change, and the erupted volume at the surface is estimated by time-integrating discharge rate calculated from the echo height using Equation (1). Figure 4 shows the geodetic volume change $\left(\Delta V_{G}\right)$ and the accumulated dense rock equivalent (DRE) erupted volume $\left(\Delta V_{D}\right)$ as a function of time in the period from January 26 to 27 . Here, $\Delta V_{G}$ and $\Delta V_{D}$ were normalized by the total geodetic change in volume and the total erupted volume in this period, respectively. A very clear correlation between $\Delta V_{G}$ and $\Delta V_{D}$ indicates that the magma discharge process at the surface was directly correlated with deflation process of the magma chamber without time lag. This suggests that a magma plumbing system connecting the magma chamber and the surface did not change substantially during the eruptions on January 26 and 27.

\section{Discussion}

The method to identify eruption styles based on tiltmeter and weather radar data presented in this study is useful for precise monitoring of eruption dynamics. Because both tiltmeter and weather radar data are telemetered, it is possible to capture the change in eruption styles even during the eruptive events. In addition, our method detected the SC events on January 29, which are accompanied by magma migration from the magma chamber and continuous tephra emission. Although the SC events

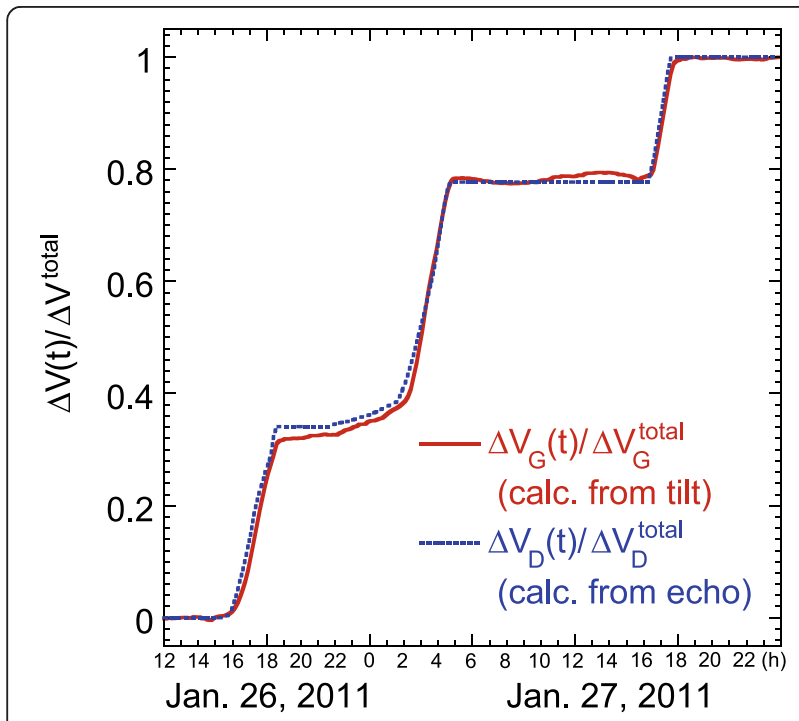

Figure 4 Volume change of the magma chamber versus erupted DRE volume on January $\mathbf{2 6}$ and $\mathbf{2 7}$. Geodetic volume change of the magma chamber $\left(\Delta V_{G}\right)$ and accumulated DRE erupted volume at the surface $\left(\Delta V_{D}\right)$ as a function of time in the period from January 26 to 27 , in which $\Delta V_{G}$ and $\Delta V_{D}$ are normalized by the total geodetic volume change and the total erupted volume in this period, respectively. Here, $\Delta V_{G}$ is estimated from tiltmeter data, and $\Delta V_{D}$ is estimated by time-integrating magma discharge calculated from cloud echo height using Equation (1). have not been listed in the JMA report, we consider that the identification of a tephra emission event like the $\mathrm{SC}$ event is important from the viewpoint of disaster mitigation.

Although our method successfully identified the eruption styles during the Shinmoe-dake eruptions, we also recognize that there are limitations to our method since both the tiltmeter and the radar measurements are affected by weather conditions. In the tiltmeter measurements, rainfall causes a nonvolcanic tilt change due to a change in the level of the aquifer. In the weather radar measurements, both rain clouds and eruption clouds are detected, as in the case of the morning on January 28 in Figure 2a (Shimbori et al. 2013), and eruption clouds are undetectable when covered by dense rain clouds. These weather effects on the two measurements may prevent precise identification of eruption styles. In order to improve the accuracy of our method, it is necessary to take into account the effect of rainfall on a tilt change by aquifer modeling (e.g., Ueda et al. 2010) and to use polarimetric weather radar for distinguishing between tephra in eruption clouds and water droplets in rain clouds (e.g., Maki and Iwanami 2002; Marzano et al. 2006). Seismic data can also be used for distinguishing between an eruptive event with volcanic seismicity and a purely meteorological event.

The agreements between our results and previous studies for the cloud height-discharge rate relationship indicate that the tiltmeter and the weather radar data during the Shinmoe-dake eruptions were successfully capturing the physics of the eruption column dynamics. Furthermore, our results show that a theoretical powerlaw scaling with 0.25 power in the cloud heightdischarge rate relationship is satisfied even in the case of a low discharge rate and strong wind. The compilations of the cloud height-discharge rate relationship in previous studies (Sparks et al. 1997; Mastin et al. 2009; Woodhouse et al. 2013) are mainly based on data with discharge rates higher than $10^{6} \mathrm{~kg} \mathrm{~s}^{-1}$ and maximum wind speeds in the troposphere lower than $40 \mathrm{~m} \mathrm{~s}^{-1}$. In contrast, the relationship in Figure 3 was obtained for the discharge rate ranging from $10^{5}$ to $10^{6} \mathrm{~kg} \mathrm{~s}^{-1}$ and the wind speed of $80 \mathrm{~m} \mathrm{~s}^{-1}$. This result supports the robustness of the theoretical power-law scaling for wide ranges of discharge rate and wind speed.

The relationship between magma chamber deflation and magma discharge processes (Figure 4) has also been investigated in the 2011 basaltic eruption of Grímsvötn Volcano by Hreinsdóttir et al. (2014) on the basis of crustal deformation and cloud height measurements. They used the pressure change instead of the geodetic volume change to describe the deflation process of magma chamber. In the Grímsvötn eruption, a clear correlation between the magma chamber deflation and the 
magma discharge has been observed and is characterized by exponential decay of the chamber pressure and discharge rate. This exponential decay is explained by the magma chamber-conduit system of fixed parameters, under the assumptions that the change in chamber pressure is controlled by magma outflux to the conduit (i.e., discharge rate), and the discharge rate is proportional to the chamber pressure (Huppert and Woods 2002; Hreinsdóttir et al. 2014). On the other hand, in the Shinmoe-dake eruptions, although a clear correlation between the chamber deflation and the magma discharge was observed, there was no exponential decay of chamber pressure and discharge rate during continuous column-forming eruptions (Figure 4). This suggests that for andesitic Plinian or sub-Plinian eruptions, we must consider more complex magma chamber-conduit systems, such as complex conduit flow dynamics, than for the basaltic eruptions (e.g., Koyaguchi 2005).

The onsets of magma chamber deflation and magma discharge are also different in the Grímsvötn and the Shinmoe-dake eruptions. The initial magma chamber deflation preceded the onset of the magma discharge in the Grímsvötn eruption (Hreinsdóttir et al. 2014), whereas the onset of the chamber deflation coincided with that of the magma discharge in the Shinmoe-dake eruptions (Figure 4). This difference results depending on whether an open conduit system has been formed before the onset of eruption; the process of the conduit system formation may induce a time lag between the onsets of chamber deflation and magma discharge. This hypothesis is supported by the contrasting features of seismicity in the two eruptions: a progressive increase in seismicity occurred before the onset of the Grímsvötn eruption (Hreinsdóttir et al. 2014), which implies conduit formation caused by magma intrusion, whereas no obvious increase in seismicity occurred before the onset of the Shinmoe-dake eruptions (Ueda et al. 2013), implying an open conduit system.

\section{Conclusions}

On the basis of the tiltmeter and the weather radar data during the 2011 Shinmoe-dake eruptions, we investigated the correlation pattern between the deflation of the magma chamber and eruption cloud height. We presented a method based on this correlation pattern to identify various eruption styles, in which we can distinguished whether a column-forming eruption is accompanied by magma migration from the magma chamber (e.g., sub-Plinian eruption), or not (e.g., Vulcanian explosion). The well-correlated chamber deflation and cloud height data provided strong constraints on eruption column dynamics and the magma plumbing system during the Shinmoe-dake eruptions. We found that even with a low discharge rate and strong wind during the Shinmoe- dake eruptions, the eruption column dynamics were well described by a one-quarter power scaling relationship between cloud height and magma discharge rate. In addition, we found a very clear correlation between the geodetic volume change of the magma chamber and erupted volume at the surface, which indicates that a stable magma plumbing system connecting the magma chamber and the surface did not change substantially during the eruptions.

Our results indicate that a simultaneous monitoring of the magma chamber and eruption cloud based on tiltmeter and weather radar data is valuable for capturing the eruption dynamics in real time. In Japan, the borehole-type tiltmeters have been set up around the main active volcanoes (e.g., V-net operated by NIED), and C-band weather Doppler radar (operated by JMA) is covering the entire country. By combining these monitoring networks, we can apply the method and the analyses for the Shinmoe-dake eruptions shown in this study to future eruptions in other volcanoes.

\section{Competing interests}

The authors declare that they have no competing interests.

\section{Authors' contributions}

TK (corresponding author) carried out the analyses for the correlation between tiltmeter and weather radar data and drafted the manuscript. HU analyzed the tiltmeter data, and TS and KF analyzed the weather radar data. All authors read and approved the manuscript.

\section{Acknowledgements}

We are grateful to the staff of NIED for construction and maintenance of V-net. GSI of Japan is acknowledged for providing digital maps. Discussions with T. Koyaguchi were fruitful. We thank Magnús T. Gudmundsson and an anonymous reviewer for insightful comments and suggestions that greatly improved the manuscript. Part of this study was supported by the Special Coordination Funds for Promoting Science and Technology from MEXT (Urgent Study on the Eruption of Mt. Shinmoe-dake, Kirishima, 2011) and JSPS KAKENHI Grant Number 24244069

\section{Author details}

'Department of Geophysics, Graduate School of Science, Tohoku University, 6-3, Aramaki Aza-Aoba, Aoba-ku, Sendai, Miyagi 980-8578, Japan. ${ }^{2}$ National Research Institute for Earth Science and Disaster Prevention, 3-1, Tennodai, Tsukuba, Ibaraki 305-0006, Japan. ${ }^{3}$ Meteorological Research Institute, 1-1, Nagamine, Tsukuba, Ibaraki 305-0052, Japan.

Received: 27 June 2014 Accepted: 1 October 2014 Received: 27 June 2014 Accepted: 1 October

\section{References}

Akaike H (1974) A new look at the statistical model identification. IEEE Trans Autom Contr 19(6):716-723, doi:10.1109/TAC.1974.1100705

Bursik M (2001) Effect of wind on the rise height of volcanic plumes. Geophys Res Lett 28(18):3621-3624, doi:10.1029/2001GL013393

Degruyter W, Bonadonna C (2012) Improving on mass flow rate estimates of volcanic eruptions. Geophys Res Lett 39(16), L16308, doi:10.1029/ 2012GL052566

Fukuoka Dist. Meteorol. Obs. and Kagoshima Local Meteorol. Obs (2013) The 2011 Eruptive Activities of Shinmoedake Volcano, Kirishimayama, Kyushu, Japan. Q J Seismol 77:65-96 (in Japanese with English abstract)

Hashimoto A, Shimbori T, Fukui K (2012) Tephra fall simulation for the eruptions at Mt. Shinmoe-dake during 26-27 January 2011 with JMANHM. Sola 8:37-40, doi:10.2151/sola.2012-010 
Hreinsdóttir S, Sigmundsson F, Roberts MJ, Björnsson H, Grapenthin R, Arason P, Árnadóttir T, Hólmjárn J, Geirsson H, Bennett RA, Gudmundsson MT, Oddsson B, Ófeigsson BG, Villemin T, Jónsson T, Sturkell E, Höskuldsson A, Larsen G, Thordarson T (2014) Óladóttir BA (2014) volcanic plume height correlated with magma-pressure change at Grímsvötn volcano. Iceland Nature Geosci 7:214-218, doi:10.1038/ngeo2044

Huppert HE, Woods AW (2002) The role of volatiles in magma chamber dynamics. Nature 420(6915):493-495, doi:10.1038/nature01211

Kato K, Yamasato H (2013) The 2011 eruptive activity of Shinmoedake volcano, Kirishimayama, Kyushu, Japan - overview of activity and volcanic alert level of the Japan meteorological agency-. Earth Planets Space 65(6):489-504, doi:10.5047/eps.2013.05.009

Koyaguchi T (2005) An analytical study for 1-dimensional steady flow in volcanic conduits. J Volcanol Geotherm Res 143:29-52, doi:10.1016/j. jvolgeores.2004.09.009

Koyaguchi T, Mitani NK (2005) A theoretical model for fragmentation of viscous bubbly magmas in shock tubes. J Geophys Res 110, B10202, doi:10.1029/ 2004JB003513

Kozono T, Ueda H, Ozawa T, Koyaguchi T, Fujita E, Tomiya A, Suzuki YJ (2013) Magma discharge variations during the 2011 eruptions of Shinmoe-dake volcano, Japan, revealed by geodetic and satellite observations. Bull Volcanol 75(3):695, doi:10.1007/s00445-013-0695-4

Maki M, Iwanami K (2002) Multi-parameter radar observations of volcanic ash clouds from Mt. Oyama in Miyake Island. Tech Note Natl Res Inst Earth Sci Disaster Prevention 226:1-21 (in Japanese with English abstract)

Marzano FS, Vulpiani G, Rose WI (2006) Microphysical characterization of microwave radar reflectivity due to volcanic ash clouds. IEEE Trans Geosci Remote Sens 44(2):313-327, doi:10.1109/TGRS.2005.861010

Mastin LG, Guffanti M, Servranckx R, Webley P, Barsotti S, Dean K, Durant A, Ewert JW, Neri A, Rose WI, Schneider D, Siebert L, Stunder B, Swanson G, Tupper A, Volentik A, Waythomas CF (2009) A multidisciplinary effort to assign realistic source parameters to models of volcanic ash-cloud transport and dispersion during eruptions. J Volcanol Geotherm Res 186(1):10-21, doi:10.1016/j. jvolgeores.2009.01.008

Miyabuchi Y, Hanada D, Niimi H, Kobayashi T (2013) Stratigraphy, grain-size and component characteristics of the 2011 Shinmoedake eruption deposits, Kirishima volcano, Japan. J Volcanol Geotherm Res 258(15):31-46, doi:10.1016/j.jvolgeores.2013.03.027

Mogi K (1958) Relations between the eruptions of various volcanoes and the deformations of the ground surfaces around them. Bull Earthquake Res Inst Univ Tokyo 36:99-134

Morton BR, Taylor GI, Turner JS (1956) Turbulent gravitational convection from maintained and instantaneous sources. Proc R Soc London Ser A 234(1196): $1-23$

Nakada S, Nagai M, Kaneko T, Suzuki Y, Maeno F (2013) The outline of the 2011 eruption at Shinmoe-dake (Kirishima), Japan. Earth Planets Space 65(6):475-488, doi:10.5047/eps.2013.03.016

Oddsson B, Gudmundsson MT, Larsen G, Karlsdóttir S (2012) Monitoring the plume from the basaltic phreatomagmatic 2004 Grímsvötn eruption - application of weather radar and comparison with plume models. Bull Volcanol 74(6):1395-1407, doi:10.1007/s00445-012-0598-9

Okada Y (1992) Internal deformation due to shear and tensile faults in a half-space. Bull Seism Soc Am 82(2):1018-1040

Ozawa T, Kozono T (2013) Temporal variation of the Shinmoe-dake crater in the 2011 eruption revealed by spaceborne (SAR) observations. Earth Planets Space 65(6):527-537, doi:10.5047/eps.2013.05.004

Sato H, Takahashi H, Yamamoto E, Fukuo N, Uehara M, Terasawa Y (1980) Development of the crustal tilt observation method using borehole-type tiltmeters. Zisin 33:343-368 (in Japanese with English abstract)

Segall P (2010) Earthquake and volcano deformation. Princeton University Press,

Shimbori T, Sakurai T, Tahara M, Fukui K (2013) Observation of eruption clouds with weather radars and meteorological satellites: a case study of the eruptions at Shinmoedake volcano in 2011. Q J Seismol 77:139-214 (in Japanese with English abstract)

Sparks RSJ (2003) Forecasting volcanic eruptions. Earth Planet Sci Lett 210(1):1-15, doi:10.1016/S0012-821X(03)00124-9

Sparks RSJ, Bursik MI, Carey SN, Gilbert JS, Glaze LS, Sigurdsson H, Woods AW (1997) Volcanic Plumes. John Wiley, Chichester UK

Suzuki YJ, Koyaguchi T (2013) 3D numerical simulation of volcanic eruption clouds during the 2011 Shinmoe-dake eruptions. Earth Planets Space 65(6):581-589, doi:10.5047/eps.2013.03.009
Takeo M, Maehara Y, Ichihara M, Ohminato T, Kamata R, Oikawa J (2013) Ground deformation cycles in a magma-effusive stage, and sub-Plinian and Vulcanian eruptions at Kirishima volcanoes, Japan. J Geophys Res 118(9):4758-4773, doi:10.1002/jgrb.50278

Turcotte DL, Ockendon H, Ockendon JR, Cowley SJ (1990) A mathematical model of vulcanian eruptions. Geophys J Int 103:211-217

Ueda H, Fujita E, Ukawa M, Yamamoto E, Irwan M, Kimata F (2005) Magma intrusion and discharge process at the initial stage of the 2000 activity of Miyakejima, Central Japan, inferred from tilt and GPS data. Geophys J Int 161(3):891-906, doi:10.1111/j.1365-246X.2005.02602.x

Ueda H, Fujita E, Ukawa M, Yamamoto E (2010) Automated technique for anomalous volcanic crustal deformation detection and source estimation by using real time tiltmeter data. Rep Natl Res Inst Earth Sci Disaster Prevention 76:21-32 (in Japanese with English abstract)

Ueda H, Kozono T, Fujita E, Kohno Y, Nagai M, Miyagi Y, Tanada T (2013) Crustal deformation associated with the 2011 Shinmoe-dake eruption as observed by tiltmeters and GPS. Earth Planets Space 65(6):517-525, doi:10.5047/ eps.2013.05.001

Woodhouse MJ, Hogg AJ, Phillips JC, Sparks RSJ (2013) Interaction between volcanic plumes and wind during the 2010 Eyjafjallajökull eruption, Iceland. J Geophys Res 118(1):92-109, doi:10.1029/2012JB009592

doi:10.1186/s40623-014-0139-1

Cite this article as: Kozono et al.: Correlation between magma chamber deflation and eruption cloud height during the 2011 Shinmoe-dake eruptions. Earth, Planets and Space 2014 66:139.

\section{Submit your manuscript to a SpringerOpen ${ }^{\circ}$ journal and benefit from:}

- Convenient online submission

- Rigorous peer review

- Immediate publication on acceptance

- Open access: articles freely available online

- High visibility within the field

- Retaining the copyright to your article

Submit your next manuscript at $\gg$ springeropen.com 